through the usual accreditation procedure. In comparison to the public universities to which they are affiliated, these institutions are permitted to enroll a considerable number of students with lower entrance examination scores but at much higher tuition rates. Consequently, many independent private institutions are left with a greatly diminished ability to attract students and investments.

A second critical challenge is the privatization of public-sector financing, which allows public institutions to expand enrollment capacity quickly. This obviously undercuts private higher education expansion. The two major privatized financing sources for public higher education consist of tuition and bank loans. While tuition compensates for the state's decreasing allocation, bank loans allow public institutions to garner as much as hundreds of millions of dollars. Such funds pose extraordinary enrollment challenges to private higher education because public institutions enhance their existing programs and add new programs and campuses.

A third challenge to China's private higher education involves public institutions' privatized management style, which imitates private business as well as the private higher education sector by adopting a market orientation. Public institutions not only improve their efficiency in management but also update their curriculum and programs, based on market demands. Private institutions thus have to reexamine their management efficiency and compete with public institutions in certain marketable fields that used to be the private sector's exclusive profitable domain.

\section{The Modification of Private Higher Education}

As the challenges from public-sector privatization modify China's private higher education development, two key trends emerge. One trend is the bifurcation of private institutions. Some institutions accumulate enormous resources, upgrade their educational quality, update program provision, enroll thousands of students, and thus gain considerable prestige and recognition while competing with public, affiliated, and other independent private institutions. But more and more independent private institutions experience hardship from the fierce new competition. Closings and mergers (from positions of weakness) are increasing.

The second trend is that the future of independent private institutions is increasingly obscure because of the rapid spread of degree-granting affiliated colleges. As the latter enjoy certain inherent advantages, numerous nonprestigious independent private colleges thus often need to accept the weakest applicants, in nondegree programs. The competition is especially difficult because China is experiencing a gradually shrinking pool of high school graduates who fail to gain admission to public universities.

While China's private higher education used to take advantage of the limited public provision, the new intersectoral competitive dynamics now present a challenge to private higher education's growth. This trend is also significantly modifying the development pattern and shape of the country's private higher education sector.

\section{New Private-Public Dynamics: Graduate Education in Uruguay}

\section{Pablo Landon I Couture}

Pablo Landoni Couture is a professor at the Catholic University of Uruguay and a PROPHE affiliate: Address: Av. 8 de Octubre 2738 Montevideo, URUGUAY CP 11600. E-mail: plandoni@ucu.edu.uy.

$\mathrm{U}$ ruguay was the last country in Latin America to authorize private higher education institutions. Current regulatory and financing arrangements contribute to a still rather limited private-public competition but that may be changing, and the graduate level is a key locus of such new competition.

\section{A New Private Sector}

Private higher education was not allowed in Uruguay until I985, when the government authorized the founding of the Catholic University. Ten years later, a new regulation was passed, opening the way for ample private growth.

Since 1995, I7 private higher education institutions have been recognized by the state. In the past Io years, the sector has expanded and now offers 98 academic programs at the undergraduate and graduate levels. Uruguay's private sector now holds I2 percent of total national enrollments, although this percentage remains far below the private sector's share in Chile, Brazil, and other countries in the region, some of which have more than half the enrollments in the private sector.

The venerable University of the Republic (Universidad de la República) is the country's only public university. It has a rather open admissions policy, and it does not charge tuition. As a consequence, the private sector is constrained in its ability to attract students, especially from low- and middle-income families. This dual nature of the system, in terms of finance, is the main reason why private-public competition at the undergraduate level remains limited.

\section{Graduate Education}

From the beginning, Uruguay's private higher education institutions developed programs at the graduate level. This focus contrasts with the almost exclusive undergraduate emphasis of early decades in the private sector in most Latin American countries. Uruguay's private higher education leaders saw graduate education as an area in which they could successfully compete with the public university.

The University of the Republic has mostly followed the traditional Napoleonic model inherited by a good number of pub- 
lic universities in Latin America. A major feature at this university is its organization into professional schools (facultades) with five- or six-year programs (seven in medicine). In that context, graduate programs have been limited to few fields of study (largely medicine and basic sciences) until recently. In $200 \mathrm{I}$, the institution regulated graduate education, introducing a key policy change for the sector: allowing tuition for professional graduate programs. This approach makes the situation in Uruguay similar to that in Argentina, where tuition, avoided at the public undergraduate level, is common at the public graduate level. Given that most Uruguayan programs at the doctoral and even master's level have an academic profile and thus do not charge tuition, competition among institutions for graduate students in professional programs is producing new private-public dynamics.

Private universities have from the start pursued a different path, with most undergraduate programs requiring just four years, in a baccalaureate format-following the US model (programs in law are an exception). Their academic focus has been to develop programs in areas with high market demand, like business administration and computer sciences. The same areas of knowledge have been developed at the graduate level. Other fields of study with important private enrollments include education and psychology, due to public failure to develop successful programs in those areas. All this is fairly typical for private higher education development in Latin America, except that Uruguay's private-sector development started later.

\section{In the last decade, graduate programs have expanded rapidly in both sectors of higher edu- cation.}

In the last decade, graduate programs have expanded rapidly in both sectors of higher education. In 2002, I,354 students were admitted to all institutions at the graduate level, 32 percent of them to private institutions. In the same year, 35 percent of graduates came from the private sector. Clearly, the private share of graduate enrollments far exceeds the private share at the undergraduate level.

In terms of programs at the graduate level, the University of the Republic accounts for 8I percent. The public share is high, largely because of the health sciences. The public university offers education in 86 specializations in medicine and nursing. Leaving those aside, the private share of Uruguay's graduate programs constitutes 34 percent.

At the doctoral level, only the public university offers authorized programs. Nevertheless, private universities are developing PhD programs jointly with international universities. Some of these programs are under review by public authorities. At the master's degree level, the private-sector's share encompasses 33 percent of the total number of programs.

\section{New Private-Public Dynamics}

Private-public relationships in Uruguay's graduate education are changing due to the increased competition, among institutions, for graduate students (and revenues) in professional programs.

The foremost example is the field of professional graduate programs in business administration, including MBAs. Challenges for the public university come not only from private universities but also from foreign universities and distance-learning providers. In 2002 , the private sector enrolled 54 percent of the graduate students in the field of business administration.

The extent to which a traditional public university has been forced by the private institutions to compete is an interesting aspect of privatization. In areas under competition with institutions outside the public sector, a generally easily accessible and hitherto free university, completely subsidized by the state, needed to develop organizational structures and strategies quite different from those long dominant at the public university.

The public university's actions aimed at the new graduatelevel competition have focused on advertisements, hiring international faculty, and "coercive isomorphism." For an institution that enjoyed a monopoly for more than I50 years, developing an advertisement campaign was a novelty. For the last three years the public university, fully financed by the community, has placed expensive paid advertisements in the press during the registration period. To improve the quality of the programs, the public university has hired international professors, as the leading private institutions were already doing.

Along with competing openly, the public university has tried to prevail by pushing through the government regulatory agency that oversees private higher education new requirements for private graduate programs, which will increase the costs of those programs. However, new standards that may augment private costs might also bolster the quality, legitima$\mathrm{cy}$, and thus attractiveness of the programs to the students both sectors want to lure.

\section{CONCLUSION}

The private higher education literature highlights the diversification effects produced by private growth. A relevant factor for private development is public-sector failure. In Uruguay, it is clear that private universities took advantage of limited public development in professional graduate education. A fresh private-public dynamic has emerged as the public university decided to charge tuition for professional graduate education. With open competition, the institution has been forced by the market to engage in private-sector-like strategies and behavior to attract students.

The impact of private higher education development in other areas - undergraduate and academic (as opposed to professional) graduate programs, especially at the doctoral levelis still mitigated by the dual nature of the system, with a fully 
subsidized public sector and a private side that does not receive public funding.

Experiences elsewhere in Latin America are mixed. Uruguay seems to follow developments in countries like Argentina, with a dominant public sector and small niches of competition including graduate education. Nevertheless, private and public institutions are increasingly engaging in a new competitive dynamic as private enrollments grow and the public university gets involved in some privatized endeavors.

\section{Dual Privatization in Georgian Higher Education}

\section{Marie Pachuashvili \\ Marie Pachuashvili is a Ph.D. candidate in political science at Central European University in Budapest, Hungary and a PROPHE affiliate. E- mail:pphpamo1@phd.ceu.hu.}

Tn postcommunist countries, a significant transformation of 1 the higher education landscape has taken place since the collapse of communism - in the form of diminished state involvement in funding, provision, and governance. The extent and shape of the shift varies by country, but all postcommunist countries witness former public monopolies challenged by some form of privatization. There is usually dual privatization: (a) the growth of private institutions and (b) the introduction of tuition fees and increased businesslike behavior at public universities. Georgia has experienced both forms of privatization.

Like many countries in the region, Georgia has almost no history of private higher education. Georgian private institutions first appeared in I991. Yet, by the 1992-I993 academic year I3I such institutions already existed. The collapse of the Georgian economy and decline in state support for public institutions contributed to diminished public-sector enrollments (an apparent parallel to trends in Central Asian and Baltic countries). Several new public institutions opened, but the public sector saw a 20 percent overall decline in the first half of the I990s. This period represented the time frame of private institutions' founding and most intensive growth. The expansion of the comparatively large private sector peaked at 34 percent of total enrollments in 1995-1996.

\section{Public-Sector Privatization}

Since that peak, however, private-sector enrollments have fallen in relative and even in absolute terms. While the first fall is not unusual in the region, the second is. Demand for publicly provided education, by contrast, has increased since I997-I998. Just as the rise in private higher education reduced public enrollments, public-sector reform is now taking a toll on the private higher education sector.
There is one leading element in the public-sector reform: the growing body of self-financed students, which is a striking aspect of privatization within the public sector both within and beyond the region. Authorization for this change came in 1993. By 2002, 43 percent of the public sector's students paid tuition, and the share has risen each year. Student payments represent the major source of income for some public universities. For instance, in 200I-2002, student tuition revenues at Tbilisi State University and the Medical University were, respectively, two and three times higher than funds received from the state.

The dependence of public institutions on student tuition fees has blurred the distinction between the activities and missions of the two sectors in Georgia. In an attempt to attract more fee-paying students, public institutions have tried hard to stay attuned to labor-market fluctuations by providing training in fields like information technology, law, business administration, and foreign languages. Today, most public educational organizations run programs in law and economics. In addition, besides the official Georgian language of instruction, courses are offered in Russian, English, German, Armenian, and Azeri. Such ethnic appeal has been a hallmark of private higher education, often frowned upon by national public institutions. Thus, the new involvement of public universities is a significant development.

\section{According to the 2004 law on higher education, successful candidates receiving the state finan- cial grant can choose from among all accredit- ed institutions, both public and private.}

Additionally, by introducing vouchers for financing higher education, the Georgian government intends to encourage even more marketlike behavior on the part of public institutions and to promote competition between and within the two sectors of higher education. According to the 2004 law on higher education, successful candidates receiving the state financial grant can choose from among all accredited institutions, both public and private. This would further blur publicprivate differences, at least in reference to accredited private institutions. Furthermore, neither public institutions, which long held a monopoly, nor private institutions, which enjoyed a period of rather easy growth during the I990s, would fare well without being competitive-both inter- and (largely) intrasectorally.

\section{CONCLUSION}

In summary, extensive privatization of the previously public higher education system has been taking place in Georgia since 1989. The shift relates to the creation and growth of a distinct private sector as well as to public institutions increasingly supplementing public funding with private resources, mostly through tuition. The Georgian case corresponds in key respects to developments in the region, but it is striking for 